\title{
SPINAL CORD INFARCTION ASSOCIATED WITH THE SICKLE CELL TRAIT
}

\author{
By L. Wolman ${ }^{1}$ and A. G. Hardy \\ Department of Neuropathology, Royal Infirmary, Sheffield, and \\ The Spinal Injuries Unit, Lodge Moor Hospital, Sheffield
}

NeURological manifestations are known to occur in patients with abnormal haemoglobins. An incidence of about 18 per cent. is recorded by Greer and Schotland (1962). The incidence is even higher in sickle cell anaemia occurring in 29 per cent. (Rowland, I95I) to about a third of all cases (Ford, 1966). The symptoms may be varied but the ones most frequently present have been accounted for by lesions in the brain (Hughes, Diggs and Gillespie, 1940), although in a recent study of the pathology in seven adults over the age of 30 (Thorburn, I969), no abnormal histological features were seen in the brain except for one case of meningitis. According to Greer and Schotland (I962), there have been no reports of spinal cord syndromes, peripheral neuropathy, myopathy or isolated cranial nerve involvement. It is therefore considered worth recording the following case report of a patient with the sickle cell trait who developed a progressive and ascending paraplegia and on whom it was subsequently possible to carry out a detailed clinicopathological correlation.

Case Report. This patient was a Jamaican lady who came to England from Jamaica in 1955 when she was 48 years old. She worked as a cleaner in an engineering works. She first complained of vague pains in various sites throughout her body over a period of six months in I96I. There had also been some loss of appetite and loss of weight over the same period. She was referred to a medical department and apart from some abdominal visceroptosis no definite abnormal physical signs were recorded on clinical examination. $\mathrm{X}$-rays of the chest, alimentary tract (barium meal) and excretory urography were reported as normal except that she had a partial double kidney on the left side. A urine culture was sterile. A routine blood examination showed an iron deficiency anaemia with haemoglobin II $\cdot 8 \mathrm{~g}$./ I00 $\mathrm{ml}$. (80 per cent.) and a slightly raised erythrocyte sedimentation rate. Faecal examination for occult blood was negative.

She was seen again in March I962 when she still did not feel well and still had vague pains in her body. A repeat barium meal and X-ray was negative and two further stools were also negative for occult blood. The blood picture was relatively unchanged. She was obviously depressed and accordingly referred to the psychiatrist, who felt that her troubles were due to the female climacteric.

In February I964 she was referred to the surgical department because of a complaint of numbness in the right leg which had appeared quite suddenly some two months previously. This was associated with symptoms of heaviness and sensations of pins and needles. No abnormal physical signs were noted but the patient was referred to the neurological department. The history of generalised pains in the body and of pain in the right hip and right leg, together with sensations of pins and needles, was repeated. There were no abnormal neurological signs recorded on clinical examination. The only recorded abnormalities were an erythrocyte sedimentation rate of $60 \mathrm{~mm}$. in I hour and a haemoglobin of $12.8 \mathrm{~g}$./ $100 \mathrm{ml}$. The pains were thought to be rheumatic in origin, and she was given prednisolone $5 \mathrm{mg}$ b.d. for a period of 3 months. During this time the pains became less and the E.S.R. dropped to $20 \mathrm{~mm}$. in I hour.

1 Deceased 
In February 1965 she was referred to the Orthopaedic Department for physiotherapy and it is noted that she still complained of intermittent attacks of pins and needles in the body and legs but she continued to work as a general cleaner, although she attended her own doctor at irregular intervals.

In May 1966 she was referred to the haematologist by her local doctor because he thought he could feel an enlarged spleen. This was not confirmed by further clinical examination but the blood condition was investigated in more detail. It was also recorded that she had worked for five years as a cleaner of engine parts using trichlorethylene and for three years as a painter of metal pipes using lead paints. No abnormal clinical features were noted, but the blood pressure was $170 / 90 \mathrm{~mm} . \mathrm{Hg}$. Routine haematological investigation revealed a normal blood picture with a haemoglobin of $13.9 \mathrm{~g} . / 100 \mathrm{ml}$. A second examination revealed reticulocytes $I \cdot 7$ per cent., IOO per cent. haemolysis in 0.28 per cent. saline, a positive sickling test, less than I per cent. of alkali-resistant haemoglobin on electrophoresis, and Itano's solubility test suggestive of haemoglobin S, both haemoglobin $A$ and $S$ being detected.

It was concluded from these tests that she had a heterozygous sickling condition, i.e. sickle cell trait. There was no family history of any blood disorder. Other investigations included serum calcium $9.4 \mathrm{mg}$./100 ml., serum magnesium phosphate $3.1 \mathrm{mg} . / \mathrm{ml}$., serum alkaline phosphatase 82 I.U. X-rays of the chest were normal; X-rays of the dorsal and lumbar spine were reported as having increased density in the middle of the vertebral bodies best seen in the lateral film of the lumbar spine.

In July I966 she was admitted to hospital complaining of weakness and stiffness of both legs and dribbling incontinence of urine over a period of two days. She was found to have a definite spastic paraparesis of both legs with increased muscle tone and also a patchy general impairment of superficial and deep sensations over the lower trunk and both legs. Cranial nerve and upper limb functions were normal. The bladder was grossly distended.

There was a rapid deterioration in the clinical signs to an almost complete paraplegia. $\mathrm{X}$-rays of the spine showed a moderate degree of cervical spondylosis with degenerative changes more marked between the 4 th and 5 th and the 5 th and 6 th cervical vertebrae than elsewhere. In the dorsal and lumbar spine the central densities of the vertebral bodies were again noted and reported to be a congenital residue of the canal of Hahn and of no particular significance. A myelogram showed a free flow of contrast through the subarachnoid space from the sacral canal to the cisterna magna. No abnormality was detected apart from minimal lateral and posterior irregularities in the cervical region.

The cerebrospinal fluid was slightly opalescent and contained 500 red cells per cu. $\mathrm{mm}$. in two specimens. The protein was $100 \mathrm{mg}$. $/ 100 \mathrm{ml}$., glucose $76 \mathrm{mg}$./100 $\mathrm{ml}$., W.R. and Lange reaction negative. Routine haematology revealed haemoglobin 13.2 g./ IoO ml., with normocytic, normochromic erythrocytes. White blood count was I I,700 per cu. mm. with neutrophils 63 per cent., lymphocytes 31 per cent. Further investigations revealed a normal serum vitamin $\mathrm{B}_{12}$ level of $875 \mu \mathrm{g}$. $/ \mathrm{ml}$.; serum electrolytes were within normal limits and no urine porphyrins or porphobilinogens were detected. The haemoglobin was $12.9 \mathrm{~g}$./ $/ 100 \mathrm{ml}$., and the erythrocyte sedimentation rate was $60 \mathrm{~mm}$. in I hour. The sickling test was still positive.

In August/September I 966 there was a little improvement in power and range of movement in both legs and some return of bladder and bowel control. There remained a spastic weakness of both lower limbs with the greatest weakness in the left leg. In October the myodil was rescreened and there was no obstruction to the flow. The erythrocyte sedimentation rate was $58 \mathrm{~mm}$. in I hour and a scalene node biopsy was negative.

In the next six months up to March 1967 she was regarded as a case of incomplete paraplegia of unproved origin and was given a general physical rehabilitation with the aid of a wheelchair. She was able to stand a little with some support but could not walk. Bladder and bowel control were present but imperfect. Complaints of pains and burning sensations in the legs were constant and there were frequent and irregular involuntary 
movements of both lower limbs. In April 1967 a rapid deterioration of the neurological condition occurred over a period of four days and this was characterised by a total loss of the pain and burning sensations in both legs and a total loss of all movement. There was also a loss of bladder and bowel control. The main complaints were now associated with the upper limbs, with burning and tingling sensations in both hands and fingers. Examination of the cerebrospinal fluid revealed normal pressure with a free rise and fall on jugular compression, a protein of $500 \mathrm{mg}$./ $100 \mathrm{ml}$., and a strongly positive globulin test. It was felt that this condition was due to an ascending myelopathy resulting from intramedullary vascular disturbances.

In May there was complete flaccid paralysis below the level of the mid chest. In June there was gross weakness in both upper limbs associated with severe painful paraesthesiae in the arms and hands. This was followed by a total paralysis of all finger and

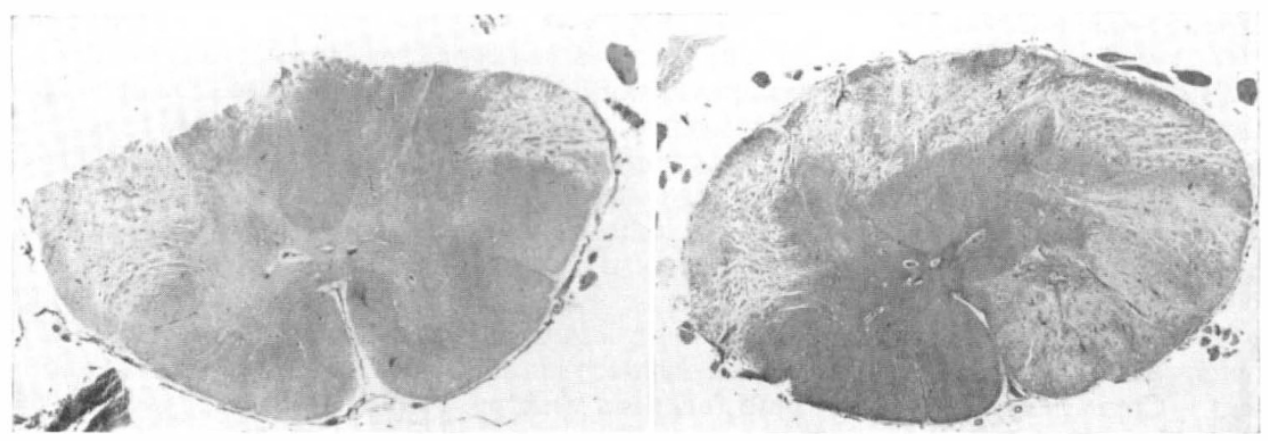

FIG. I

FIG. 2

Fig. I.-Transverse section of cervical cord at the level of $\mathrm{C}_{2}$ showing three wedge-shaped areas of infarction. Mallory's P.T.A.H. $\times 54$.

Fig. 2.-Transverse section of spinal cord at the level of $\mathrm{C}_{3}$ showing an arcuate area of infarction extending round the dorsal half and separated from the surface by a layer of intact tissue with a large infarct involving one anterior horn. Myelin. $\times 5.4$.

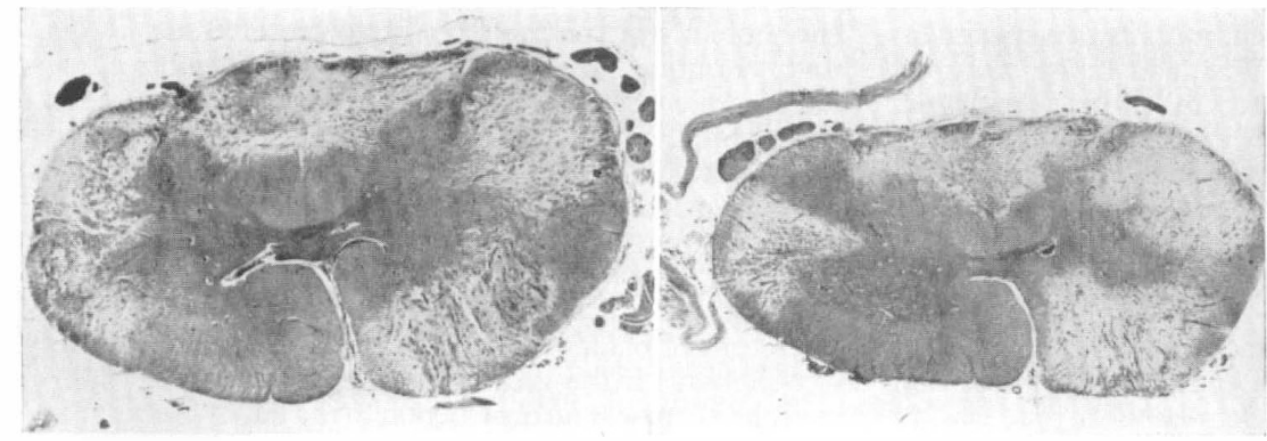

FIG. 3

FIG. 4

Fig. 3.-Transverse section at the level of $\mathrm{C}_{4}$ showing wedge-shaped anterolateral and dorsal arcuate infarcts. Myelin. $\times 5.4$.

Fig. 4.-Transverse section at the level of $\mathrm{C}_{7}$ showing four discrete wedge-shaped infarcts. Myelin. $\quad \times 48$. 
hand movement with spread of the painful paraesthesiae to the shoulders and neck. In July she was almost completely tetraplegic with increasing respiratory embarrassment. Death from respiratory failure ensued on 7 th August 1967.

Necropsy Examination (23 hours after death). The body was that of a poorly nourished elderly coloured West Indian female. Scars were present on the medial aspect of the left knee and on the anterior aspect of the left upper thigh from previous operations. There was a small superficial sacral pressure ulcer. The mucosa of the trachea and bronchi was congested, inflamed and covered with muco-pus. The lungs were congested and oedematous. The heart was of normal size and healthy in appearance. The aorta, carotid and coronary arteries were free from atheroma. The liver and spleen, both moderately enlarged, on sectioning appeared firm and congested. There was a haemorrhagic cystitis and ascending pyelitis. Multiple small fibroids were present in the uterus.

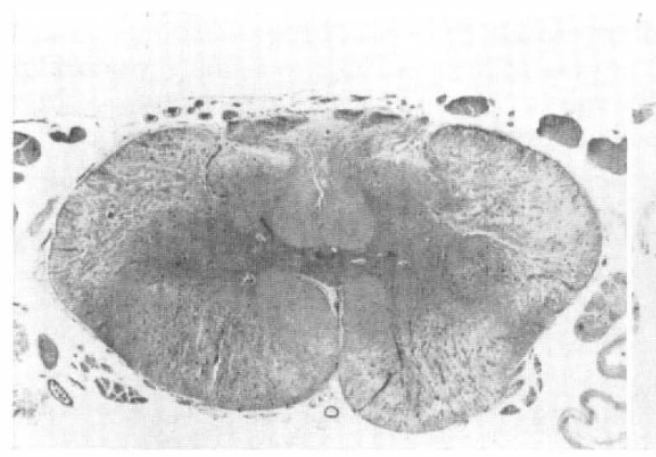

FIG. 5

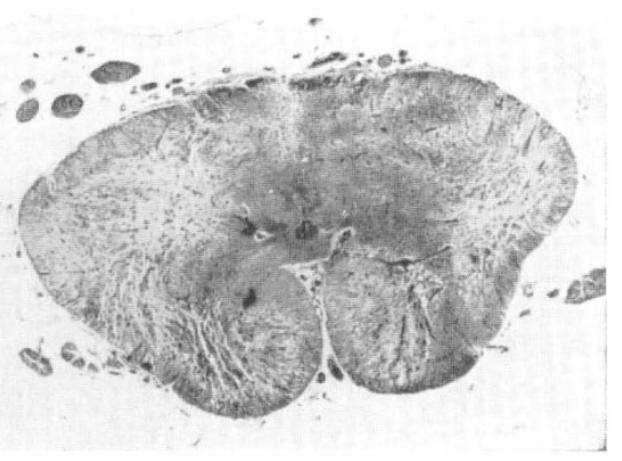

FIG. 6

Fig. 5.-Transverse section of the thoracic cord at the level of Di showing extensive bilateral necrosis of the white matter of all three columns. Myelin. $\times 5.4$.

Fig. 6.-Transverse section at the level of $\mathrm{D}_{3}$ showing extensive necrosis of the deep white matter with escape at the periphery. Myelin. $\times 7 \cdot 2$.

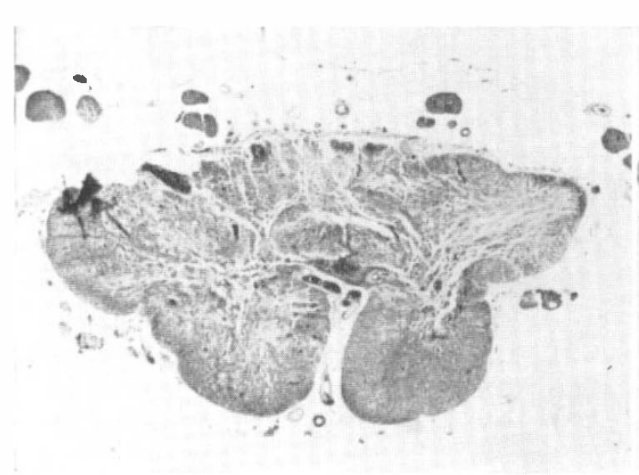

FIG. 7

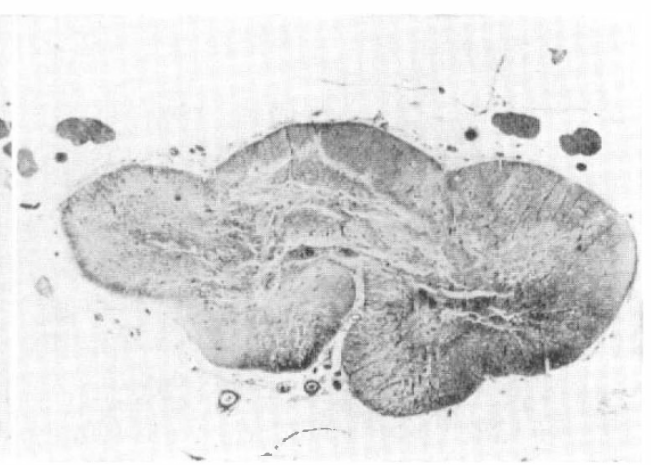

FIG. 8

Fig. 7.-Transverse section at the level of $\mathrm{D}_{4}$ showing extensive necrosis of cord apart from the ventral part of the anterior columns. Myelin. $\times 7 \cdot 8$.

Fig. 8.-Transverse section at the level of $\mathrm{D} 9$ showing necrosis with escape of the ventral columns more on one side than the other. Myelin. $\times 8 \cdot 4$. 
FIG. 9

Transverse section of the sacral cord at the level of $\mathrm{S}_{3}$ shows several small areas of perivascular necrosis in the grey matter of the anterio horns. Mallory's P.T.A.H. $\times 6$.

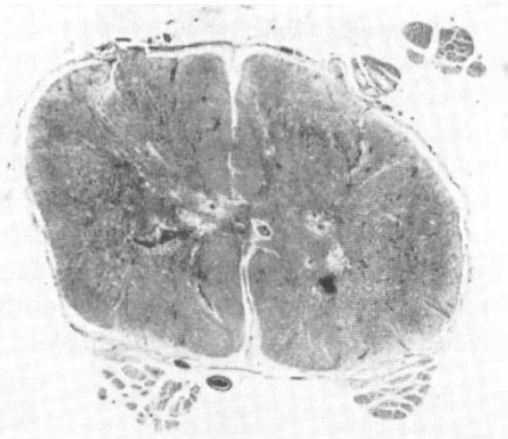

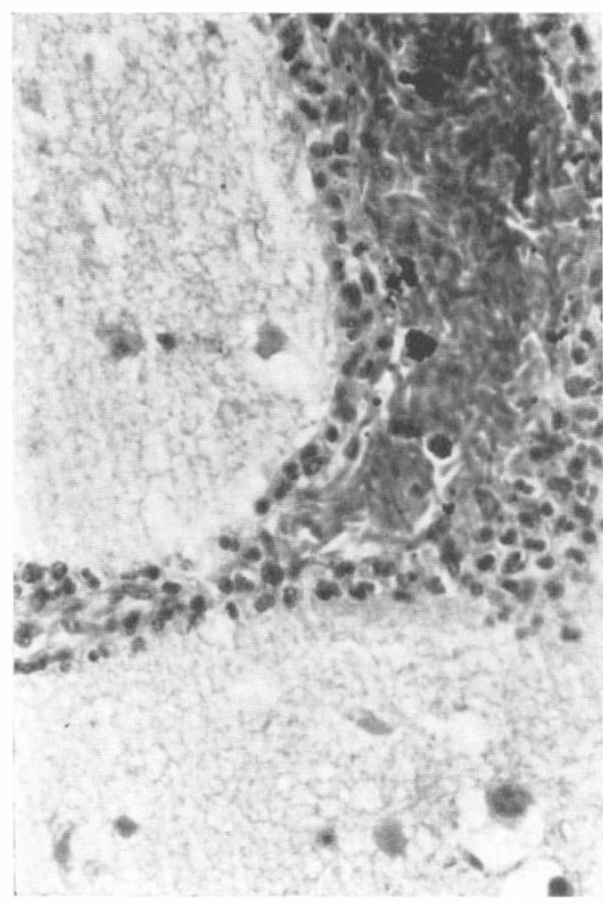

FIG. IO

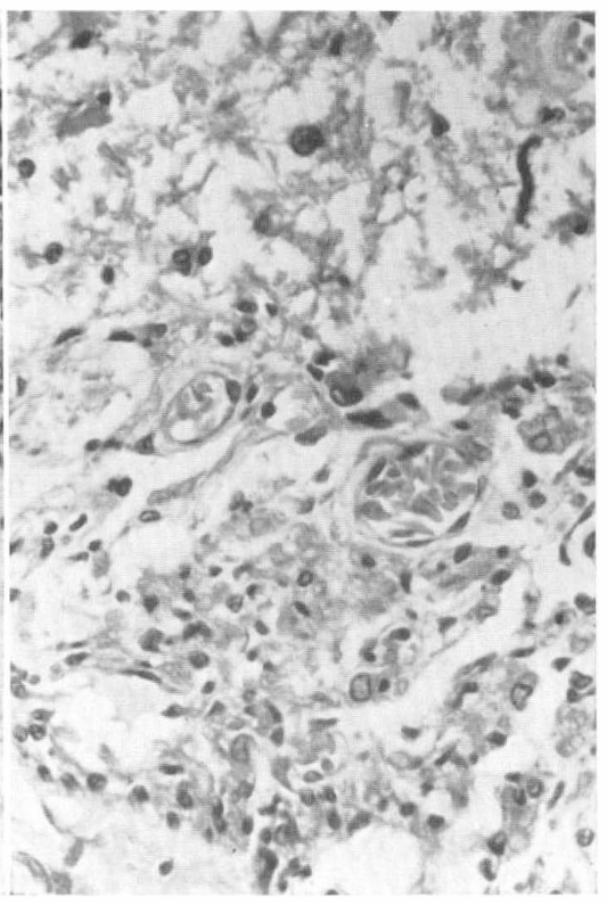

FIG. II

Fig. I0.-Vein in grey matter of sacral cord $\left(\mathrm{S}_{3}\right)$ distended with sickle shaped cells and cuffed with polymorphs and lymphocytes. Haematoxylin and Eosin. $\times 3$ I2.

Fig. I I.-Arterioles filled with sickle cells from micro-infarct of cervical cord. Lymphocytes and histiocytes are present in surrounding tissue. Haematoxylin and Eosin. 
The brain (weight II90 g.) appeared normal although pale in colour and the vessels at its base showed minimal atheroma. The spinal cord was slightly swollen in the upper cervical region whereas the thoracic and lumbar segments looked atrophic. The vertebral bodies appeared intact and no bony injury or tumour deposits could be recognised.

Microscopically small wedge-shaped infarcts were seen in the right precentral and post-central gyri at the summits of the convolutions and in the septal region. Many histiocytes were present in the necrotic areas in which cyst formation had occurred. Several similar wedge-shaped infarcts were seen in the cerebellar folia. Small areas of infarction were found in the brain-stem, situated in the upper pons in the subependymal tissue in the lateral wall of the upper part of the 4 th ventricle on each side and in the lower medulla in the dorsolateral aspect on each side separated from the surface by a layer of intact tissue. No thrombosed vessels were seen, but many vessels filled with crescenticshaped red blood corpuscles were noted, especially in the infarcted areas.

The spinal cord also showed numerous scattered areas of infarction of varying size, shape, age and distribution. In the upper cervical segments there were three areas of infarction, a small one in the midline on the dorsal aspect involving the posterior part of both posterior columns and larger wedge shaped areas in each lateral column (fig. I). There was marked capillary proliferation and numerous histiocytes and lymphocytes in the affected areas. At the level of $\mathrm{C}_{3}$ and 4 , the three areas of infarction had coalesced to a semi-arcuate area extending from one lateral column across the posterior horns and columns into the opposite side with a layer of intact tissue over the surface (fig. 2). There was also a large wedge-shaped infarct in the anterolateral column on one side extending inwards to involve the anterior horn (fig. 3). The lower cervical segments showed four discrete areas of infarction involving the posterior columns, both lateral columns and one ventral column extending into the anterior horn (fig. 4). In the upper thoracic segments these areas of infarction had coalesced to involve the white matter of the ventral, lateral and posterior columns adjacent to the grey matter (figs. 5 and 6). The thoracic segments from $\mathrm{D}_{4}$ downwards showed almost complete necrosis of the cord apart from the ventral part of the ventral column (figs. 7 and 8). The infarction in this region appeared to be of longer duration. In the lumbar cord the infarcts were again discrete involving the dorsal, lateral and ventral columns, the latter unilaterally. In the sacral cord there were small perivascular areas of destruction mainly in the grey matter of the anterior horns (fig. 9). No thrombosed vessels were seen in relation to any of these areas of necrosis but many arteries and veins were distended with abnormally shaped sickle red cells (figs. Io and I I).

\section{DISCUSSION}

The onset of a vague illness in a 54-year-old Jamaican lady raised many problems in diagnosis. At first the main symptoms were variable pains in the body and a feeling of malaise. Apart from an iron-deficiency anaemia and a slightly raised sedimentation rate, initial investigations were normal. The persistence of symptoms over the next year, accompanied by feelings of depression, led to a psychiatric diagnosis of menopausal depression. Two years later she developed numbness in the right trunk and leg. There were no physical signs, but in view of the elevated sedimentation rate a rheumatic origin was considered and treatment with prednisolone commenced with some improvement. In the following year she complained of paraesthesia in the body and legs and was given physiotherapy. Fifteen months later her general practitioner thought her spleen was palpable, and although this was not confirmed a complete haematological investigation established the presence of the sickle cell trait.

The onset of paraplegia with dribbling incontinence two months later and just over a year before her death again led to a series of negative investigations apart 
from a high sedimentation rate and a markedly increased protein content in the C.S.F. The paraplegia remained stationary for about nine months, when she began to get tingling in the hands and fingers, followed by weakness of the hands. This was accompanied again by elevation of the C.S.F. protein to $500 \mathrm{mg}$. $/ 100 \mathrm{ml}$. without any evidence of a spinal block. The weakness in the upper limbs increased in the last three months of life and finally extended to the respiratory muscles.

The autopsy examination showed enlargement of the liver and spleen but no infarction had occurred in these viscera. There were numerous infarcts of varying age and size in the central nervous system. Although these were found in cerebral cortex, cerebellum and brains-stem they were most numerous in the spinal cord. The thoracic cord showed almost complete necrosis from the level of $\mathrm{D}_{4}$ downwards and this appeared to be of longest duration. Small multiple discrete areas of infarction of more recent origin were present in the lumbosacral segments and in the cervical cord. Some of these areas were wedge shaped; others were in the watershed territory between anterior and posterior spinal arteries. Their appearance was similar at several levels to those seen in cases of spinal cord embolism (Wolman and Bradshaw, 1967). In the absence of coronary heart disease, aortic atheroma and degenerative disease of the cerebral and spinal arteries it seems likely that the only blockage of vessels of similar calibre to those in which emboli could become impacted would result from the abnormal tendency of the red blood corpuscles to sickle and clump.

The clinical entity of sickle cell anaemia (Herrick, I9I0) has been known to produce cerebral manifestations since they were first reported by Sydenstricked, Mulherin and Houseal (1923). At least 45 cases were collected by Bloch, Waldron and Cogan (195I) in their review. Bauer (1940) first suggested that the phenomena of vascular occlusion could occur independently of anaemia as a result of the sickling tendency alone. Although the pathological findings in the spinal cord in a case of sickle cell anaemia, consisting of focal areas of haemorrhage and nerve cell degeneration with small haemorrhages in the spinal meninges, were described by Yater and Hansmann (1936), the spinal cord has been studied inadequately in most reports. The findings of gross lesions in the present case fulfil the prediction made by Hughes et al. (1940) and are of special interest as occurring without the anaemia in a case with the trait.

It is known that reduced haemoglobin $S$ has 2 per cent. of the solubility of the oxygenated form. Hypoxia will therefore tend to cause sickling of cells. The abnormally shaped red cells will obstruct the small blood vessels owing to the increased viscosity of the blood and stasis, producing vascular and perivascular damage due to ischaemia. Thus in the absence of any evidence of primary vascular disease, thrombosis or source of origin of emboli, the sickle cell trait appears to be the most likely explanation for the numerous spinal cord microinfarcts. There was no evidence of fat or marrow embolism resulting from necrosis of bone marrow which occasionally occurs in sickle cell anaemia (Wade and Stevenson, I94I; Vance and Fisher, 194I; Shelly and Curtis, 1958). Although thromboses in cerebral vessels have been described in relation to infarcts in the brain in at least four cases (Kimmelstiel, 1948), no thrombosed vessels were recognised in the present case, and this has been the experience of others (Baird et al., 1964). Many small vessels stuffed with tangles of abnormally shaped red cells were seen, however, in relation to the infarcts, and although similar distended vessels occurred in areas remote from infarcts they were never as prominent. Not a great deal of significance can 
be attached to these observations owing to the sickling phenomenon increasing as the circulation fails terminally. Another way in which myelopathy can develop is mentioned by Ford (I966), who states that compression of the spinal cord or spinal nerve roots may result from collapse of vertebrae due to bone infarctions. No evidence of this or of spinal canal block was found in the present case, and although the protein content of the C.S.F. was severely elevated intermittently on several occasions, this accompanied the infarctions of the cord, as seen in retrospect.

Although intravascular sickling can occur under physiological conditions in homozygous patients with haemoglobin S-S (sickle cell anaemia) it is unlikely in heterozygous patients with a mixture of haemoglobin $\mathrm{S}$ and $\mathrm{C}$ (sickle cell disease) or haemoglobin $S$ and A (sickle cell trait). This is supported by the observation that splenic infarction occurs spontaneously in sickle cell anaemia at sea level, at 6000-feet altitude in cases of $\mathrm{Hb} \mathrm{S}-\mathrm{C}$ and only at even higher altitudes in sickle cell trait (Ober, Bruno, Simon and Weiner, 1959). While this factor may not apply uniformly to all tissues, there is increasing evidence that visceral infarction can occur in sickle cell trait especially if other diseases or anoxaemic states should develop. Thus McCormick (I96I) found one or more visceral infarcts in I 8 per cent. of 120 cases of sickle cell trait examined at autopsy in which other causes were excluded. In two of these the brain was involved. Ende, Pizzolato and Ziskind (I955) reported four similar cases, in one of which there was cerebral damage. It is interesting to speculate whether infection as suggested by the elevated sedimentation rate or an iron-deficiency anaemia which was detected in our case on the initial investigation could have played any part in precipitating the sickling process and initiating clumping, ischaemia and micro-infarction. The anaemia had been corrected by the time the paraplegia became established, but doubtless the vasomotor disturbances in the paralysed areas would provide other factors contributing to the further progression and deterioration in the neurological condition.

\section{SUMMARY}

Progressive paraplegia with an ascending level is described in a 60-year-old coloured Jamaican woman who was found to have the sickle cell trait. Death resulted from respiratory failure and subsequent autopsy revealed several small infarcts of varying age confined to the central nervous system. Although some infarcts were found in the cerebral cortex, cerebellum and brain-stem they were most numerous and extensive in the spinal cord. The pattern of the micro-infarcts is described at the various segmental levels of the cord and resembled that seen in cases of spinal cord embolism. Although no fibrin thrombus was seen in vessels associated with the necrotic areas, many were found to be distended with plugs of tightly packed abnormally shaped red cells, which would tend to cause ischaemic infarction by their increased viscosity leading to further sickling of red cells. The difficulties and problems in diagnosis are reviewed.

\section{ACKNOWLEDGMENTS}

We have had full access to the many clinical records and laboratory reports associated with this case. We thank Dr. R. J. Twort, Dr. W. B. Matthews, Dr. W. S. Whimster and Dr. D. R. Ryrie for their kind co-operation in these matters. We would also like to thank Dr. K. M. Ogilvy who performed the autopsy and allowed us to use her report and specimens. 


\section{RÉSUMÉ}

Un cas de paraplégie avec un niveau ascendant a été décrit chez une femme indigène de 60 ans chez qui a été diagnostiqué une hémoglobinopathie avec 'hémoglobine $S$ '. La mort a été due a une insufisance respiratoire et l'autopsie a montré plusieurs petits infarctus, d'âges variables, au niveau du systhème nerveux central.

Bien que quelques infarctus ont été trouvés au niveau du cortex cérébral, le cervelet et le bulbe, ils étaient plus nombreux, et plus importants, au niveau de la moëlle épinière.

La description de ces micro-infarctus au niveau de différents segments médullaires a été donnée, et, ressemble aux cas d'embolie vasculaire médullaire.

Bien qu'aucun thrombus fibrineux n'a été vu à l'examen direct dans les vaisseaux irrigant les zones nécrotiques, par contre, des obstructions vasculaires composées de globules rouges anormaux entassés ont été retrouvées, expliquant ainsi l'infarction ischémique par leur augmentation de viscosité.

Les difficultés et les problèmes du diagnostic ont été discutés.

\section{ZUSAMMENFASSUNG}

Ein Fall einer 60 jährigen Negerin aus Jamaica wird beschrieben, bei der Sichelzellbildung im Blut gefunden wurde. Sie starb an Atemlähmung und die Autopsie entdeckte mehrere kleine Infarkte im Zentralnervensystem. Obwohl einige Infarkte im Cortex, Cerebellum und Hirnstamm gefunden wurden, die Mehrzahl und ausgedehnten waren im Rückenmark. Die Anlage der Mikroinfarkte in den verschiedenen Segmenthöhen wird beschrieben und sie ähneln denen bei Embolie des Rückenmarks beschriebenen. Obwohl kein Fibrinthrombus in den Gefässen assoziiert mit Nekroseherden gefunden wurde, viele Gefässe waren erweitert und voll gepfropt mit anormalen Formen von Erythrozyten, welche eine Tendenz zur ischaemischen Infarktbildung durch erhöhte Viskosität haben und zu vermehrter S-Erythrozytenformation führen. Die Schwierigkeiten des Diagnoseproblems werden beschrieben.

\section{REFERENCES}

Baird, R. L., Weiss, D. L., Ferguson, A. D., French, J. H. \& Scott, R. B. (I964). Studies in sicke cell anemia. Clinico-pathological aspects of neurological manifestations. Pediatrics, 34, 92-100.

Bautr, J. (I940). Sickle cell disease. Pathogenic, clinical and therapeutic considerations. Archives of Surgery, 4I, I344-I362.

Bloch, H., Waldron, R. J. \& Cogan, G. M. (I95I). Sickle cell disease. Report of a case with anemia, subarachnoid hemorrhage and cerebral thrombosis. Fournal of Pediatrics, 38, 88-90.

Ende, N., Pizzolato, P. \& Ziskind, J. (1955). Sicklemia. Annals of Internal Medicine, 42, $1065-1075$.

Ford, F. R. (I966). Diseases of the Nervous System in Infancy, Childhood, and Adolescence. 5th edition. p. 84I. Springfield, Illinois: Charles C. Thomas.

GreER, M. \& SCHOTLAND, D. (I962). Abnormal hemoglobin as a cause of neurologic disease. Neurology, 12, I I4-I23.

Herrick, J. B. (I9I0). Peculiar elongated and sickle-shaped red blood corpuscles in a case of severe anemia. Transactions of the Association of American Physicians, 25, 553-56I.

Hughes, J. G., Diggs, L. W. \& Gillespie, C. E. (I940). The involvement of the nervous system in sickle cell anemia. Fournal of Pediatrics, 17, I66-I84.

Kimmelstiel, P. (I948). Vascular occlusion and ischemic infarction in sickle cell disease. American fournal of Medical Sciences, 2I 6, I I-I9.

McCormick, W. F. (I96I). Abnormal hemoglobins. The pathology of sickle cell trait. American fournal of Medical Sciences, 24I, 329-335.

Ober, W. B., Bruno, M. S., Simon, R. M. \& Weiner, L. (I959). Hemoglobin S-C disease with fat embolism. Report of a patient dying in crisis; autopsy findings. American Fournal of Medicine, 27, 647-658.

Rowland, L. P. (I95I). Neurological manifestations in sickle cell anemia. Archives of Neurology and Psychiatry, 66, 658-9. 
SHELlEy, W. M. \& CurTis, E. M. (1958). Bone marrow and fat embolism in sickle cell anemia, and sickle cell-hemoglobin C disease. Bulletin of fohns Hopkins Hospital, I 03, 8-25.

Sydenstricked, V. P., Mulherin, W. A. \& Houseal, R. W. (I923). Sickle cell anemia. Report of two cases in children with necropsy in one case. American fournal of Diseases of Children, 26, I32-I 54.

Thorburn, M. J. (1969). The pathology of sickle cell anaemia in Jamaican adults over 30. Transactions of the Royal Society of Tropical Medicine and Hygiene, 63, I02-I I I.

Vance, B. M. \& FisheR, R. C. (I94I). Sickle cell disease. Two cases, one presenting fat embolism as a fatal complication. Archives of Pathology, 32, 378-386.

WADE, L. J. \& STEVENSON, L. D. (I94I). Necrosis of the bone marrow with fat embolism in sickle cell anemia. American fournal of Pathology, 17, 47-54.

Wolman, L. \& Bradshaw, P. (1967). Spinal cord embolism. fournal of Neurology, Neurosurgery and Psychiatry, 30, 446-454.

YATER, W. M. \& HANSMANN, G. H. (1936). Sickle cell anemia: new cause of cor pulmonale; report of two cases with numerous disseminated occlusions of small pulmonary arteries. American fournal of Medical Sciences, 191, 474-484. 